\title{
New company to target technology transfer
}

\section{Paris}

FRENCH research organizations are forming an independent company to work with industry to translate their discoveries into commercial products.

The new company, which will be launched in June, plans to offer government scientists full intellectual property rights and full royalties on licences from patents based on their research in exchange for the laboratory paying all costs for the transfer of the technology to the private sector. Laboratories that prefer less risk can pay a portion of the costs in exchange for a negotiated division of the royalties.

The company will take over some of the duties of the national agency charged with promoting innovation as well as promoting technology transfer. The agency, called ANVAR (Agence Nationale de Valorisation de la Recherche), decided last year to concentrate on promoting and financing innovation. That left a vacuum that the ministers of Industry, Dominique Strauss Kahn, and of Research and Technology, Hubert Derian, rushed to fill.

A study by Jean-Claude Derian, former science adviser at the French embassy in Washington, called for a company with a budget of FF50 million (US\$8.5 million) that would both broker licences and provide venture capital for promising ideas. The structure agreed last month, however, will focus on patenting and licensing and have a budget of only FF5 million $(\$ 850,000)$ and a staff of seven. Jean RemiGouze, deputy executive director of ANVAR, explains that "the Ministry of Finance has argued that the creation of a state-owned venture capital company is unnecessary".

The Centre National de la Recherche Scientifique (CNRS), the agency that funds most basic research in France, and ANVAR will each provide about onethird of the total, with smaller amounts coming from other government funding agencies and universities. Opting out for the moment are the Institut National de la Santé (INSERM), which funds biomedical research, and the Commissariat à l'energie Atomique (CEA), which funds energy research, both of which have welldeveloped technology transfer offices.

The origins of the new company can be traced to 1982, when the French government broke ANVAR's monopoly on technology transfer by allowing laboratories greater freedom to exploit their inventions.
Since then, technology brokerage organizations have proliferated, but for the most part they have specialized in transferring their technologies to local enterprises. Few organizations have had the means to work with international companies, however, a major goal of the new company. Officials point out that the bulk of the revenues from the British Technology Group, for example, comes from foreign sources.

The new company will survive only by acquiring a sufficient number of patents. It is counting on most of ANVAR's current portfolio, which includes a large number of CNRS patents, and adding new patents at the rate of 125 a year. "If it doesn't achieve these targets", warns Gouze, "it will go under".

The almost unanimous backing of the French research establishment is expected to help the company to gain credibility on the international scene. But its chief executive officer, to be named soon, must also possess a rare combination of technical, entrepreneurial and administrative talents. Gouze says the government is looking for what the French call "un mouton à cinq pattes", or, translated loosely, something that does not exist.

David Bakewell

\section{Scientists emerge with favoured status}

\section{Hong Kong}

CHINA's scientific community stands to be a major beneficiary of the new economic reforms advanced by Deng Xiao-ping, the country's 87-year-old leader. With bonuses for thousands of civilian scientists, fewer restrictions on travel, more joint ventures with outsiders and increased spending on research, the importance of technological progress is expected to be a major theme of the current annual session of the National People's Congress, which opened last week in Beijing.

The link between reform and science was made clear earlier this month at a meeting of the State Science and Technology Commission. Li Xu, vice-minister of the commission, declared that "establishing more share-holding companies and issuing bonds in [high-technology] districts ... are effective ways to accumulate capital for money-starved research". This week's congress is expected to adopt a measure that would guarantee investment in science, require agriculture and industry to adopt the latest technologies, encourage international cooperation and protect the rights of scientists.

Some 27 high-technology development districts throughout China will receive the largest measure of freedom. These districts, the first of which was set up four years ago in Beijing, are seen as the most promising way to bring the country's products to the international market.

But not every aspect of the plan is on such a grand scale. Individual scientists and research teams will be paid bonuses for outstanding achievements. The Ministry of Personnel intends to award an extra 100 yuan (US\$18.50) a month to "the most promising middle-aged and young scientists". That is a significant addition to the US\$100-120 paid monthly to the average faculty member.

Last year, more than 9,000 people described as "experts and scholars" received such extra allowances. That group is believed to include military researchers, doctors and technicians. The new program extends such bonuses for the first time to large numbers of scientists in the civilian sector. "We guarantee that outstanding enterprises and individuals will get high pay," says Li.

Deng began his campaign in January with a well-publicized visit to Guangdong, the province in southern China in the forefront of the country's modernization. The special economic zones at Shenzhen and Zhuhai have tapped into sizeable investments by high-technology companies in neighbouring Hong Kong and Macao.

A recent report by the science commis- sion noted that "we encourage Chinese enterprises to set up joint ventures, research institutions and information service units in foreign countries". Speaking to the China Daily, Beijing's official English language newspaper, $\mathrm{Li}$ was quoted as saying that "the process of leaving and returning to the country will be greatly simplified. Scientists are now free to come and go."

China is also looking overseas for scientists. Reports from the meeting of the science commission suggest that the government wants to import technicians and scientists from the former Soviet Union, in particular from Russia, Ukraine, Byelorus, Uzbekistan and Kazakhstan. And the forthcoming Earth Summit in Brazil will see China "negotiate and cooperate with other countries in solving environmental and development problems", according to a statement from the science commission.

The focus on science and technology extends beyond diplomacy to bricks and mortar. For example, construction is well under way at the Shangdi Information Industry Base in the western suburbs of Beijing. Part of the city's high-technology development zone, the complex covers 1.8 square kilometres and, when completed, will have room for more than 100 companies.

Peter Gwynne 